\title{
Abbreviations Used in the Notes
}

$\begin{array}{ll}\text { A } & \text { America } \\ C & \text { Commonweal } \\ C H R & \text { Catholic Historical Review } \\ C M & \text { Catholic Mind } \\ C W & \text { Catholic World } \\ H L R & \text { Human Life Review } \\ M A & \text { Modern Age } \\ N C R & \text { National Catholic Reporter } \\ \text { NOR } & \text { New Oxford Review } \\ N R & \text { National Review } \\ R & \text { Ramparts } \\ S O & \text { Social Order } \\ T & \text { Triumph }\end{array}$





\section{Catholic Intellectuals and Conservative \\ Politics in America, 1950-1985}


